\title{
THE POLITICS OF PLACE: REGIONALISM AND LOCAL COLOR FICTION IN NINETEENTH-CENTURY U.S. LITERATURE
}

\author{
Kari Meyers Skredsvig
}

\begin{abstract}
RESUMEN
Este artículo es el primero de una serie dedicada a las relaciones entre autoría femenina y la noción de lugar/espacio en la literatura estadounidense. Se presenta un panorama general a fin de contextualizar el regionalismo y el localismo como movimientos literarios y como subgéneros literarios en el desarrollo de la literatura estadounidense del siglo diecinueve, mediante el análisis de los contextos históricos, sociales, políticos y literarios que inicialmente propiciaron estas dos tendencias literarias y posteriormente influyeron en su desaparición. También se examina el contenido cultural y aporte literario de estas etiquetas, así como la posibilidad de intercambiarlas.
\end{abstract}

\begin{abstract}
This is the first in a series of articles dealing with the interrelationships of female authorship and space/place in U.S. literature. This article provides an overview for contextualizing regionalism and local color both as literary movements and as literary subgenres in the development of nineteenth-century U.S. literature by exploring the historical, social, political, and literary environments which initially propitiated and later influenced the demise of these two literary tendencies. It also examines the cultural and literary import of these labels, as well as their possible interchangeability.
\end{abstract}

Place and space are components of human reality at its most fundamental level. In The Poetics of Space, Gaston Bachelard affirms that our home is "our first universe, a real cosmos in every sense of the word" (1994: 4). We construct a personal identity not only for and within ourselves, but inevitably grounded in our context, at the same time that the environment constructs us. When a person appears to have a clear sense of self and to cope effectively with everyday reality, we even say s/he is "grounded," as though that primal connection to the earth were a requisite for dealing with life optimally. Folk wisdom is full of references to the importance of place in our everyday lives, for example, in sayings such as "there's no place like home" and "home is where the heart is." The relationships among literature, place and space are as varied and complex as they are ubiquitous. For example, formalist critics examine "setting" as a fundamental element of prose, a key aspect of creating meaning through structure, while historicists affirm that not only are the spacial and temporal coordinates of human action inevitably entrwined, but also that it is impossible for the writer, the critic, and 
the reader to divorce themselves from their contexts. Psychoanalytic critics explore the connections between literary space and psychic realities, whether examining literature as an expression of personal space (identity) or as the site of deferred desire. Literary sociologists and historians frequently examine literature as a vehicle for constructing identity in a more prosaid, traditional sense, such as national and group identities. In this vein, my main interest here is to examine the place and significance of one conceptualization of spaceregionalism - in the development of U.S. literature.

In Sensational Designs, critic Jane Tompkins asserts that when literary texts are seen "not as the ineffable products of genuis but as the bearers of a set of national, social, economic, institutional, and professional interests" their stature is perceived as "less the result of their indisputable excellence than the product of historical contingencies" (xii). She proposes a "redefinition of literature and literary study [...which] sees literary texts not as works of art embodying enduring themes in complex forms," but rather as "powerful examples of the way a culture thinks about itself, articulating and proposing solutions for the problems that shape a particular historical moment" (xi). This is precisely what she defines as "the cultural work of fiction," that is, the ways in which authors and literary texts both manifest and interact with their cultural context. Changing the critical focus not surprisingly may bring to light a significantly different set of issues, or result in seeing previously identified issues in significantly innovative ways. This is true of both cultural and aesthetic valuations, which leads Tompkins to emphasize "the relationship between aesthetic value and the text's historical existence": "The text succeeds or fails on the basis of its 'fit' with the features of its immediate context, on the degree to which it provokes the desired response, and not in relation to unchanging formal, psychological, or philosophical standards of complixity, or truth, or correctness" (xviii). It is within the context of acknowledging that the historical conditions "are not external to the systems of valuation that they modify, but are themselves articulated within them" (195) that Tompkins argues her case:

I see [literary texts] as doing a certain kind of cultural work within a specific historical situation, and value them for that reason. I see their plots and characters as providing society with a means of thining about itself, defining certain aspects of a social reality which the authors and their readers shared, dramatizing its conflicts, and recommending solutions. It is the notion of literary texts as doing work, expressing and shaping the social context that produced them, that I wish to substitute finally for the critical perspective that sees them as attempts to achieve a timeless, universal ideal of truth and formal coherence [. . . ]. [Literature] provides people with an image of themselves and of their history, with conceptions of justice and of human nature, attitudes towards race, class, sex, and nationality (200-1).

It is from this perspective that I will examine U.S. literary regionalism, as not only a literary phenomenon but also a cultural one.

In both literary and cultural terms, regionalism in the U.S. is a curiously amorphous concept. In spite of its primacy as a touchstone of imaginary space and psychic identities, there have been relatively few attempts to define it. Rather, it seems to form part of a social mythology which, like so many collective assumptions, presupposes a consensus of both essence and referentiality. More often than not, it is employed without any previously articulated definition, which allows it to be appropriated to refer to everything from the country as a whole-which has been especially significant historically - to any given area 
within it, whether the size of a national quadrant or of a village. Another significant aspect of its semantic history is that its import and implications depend largely upon the user and the reader/listener; it has been employed with an entire gamut of connotations ranging from proud affirmation to derogatory dismissal, and in situations which are sufficiently diverse and complex to permit the former to be intended but the latter to be understood, or vice versa. As we explore "regionalism" in U.S. society and literature, it is helpful to keep in mind Thomas McLaughlin's introductory comments to Critical Terms for Literary Study, in which he reminds us that while terms are essential to discourse, they necessarily participate in larger social and cultural debates both through their historicity and by positioning the user (4). Terms are by nature social and thus political:

\begin{abstract}
A "term" is a boundary line, a line of demarcation. If defines a field in which work can be done, within the limits of the term. But like all boundaries, even those meticulously surveyed, terms are social and arbitrary, not natural and inevitable [...]. They limit and regulate our reading practices. But they do not do so by divine fiat [...]. Learning how terms work is part of learning how meaning is produced, and this, in turn, is part of the process of entering into that productive activity (7).
\end{abstract}

An understanding of the term "regionalism" in its U.S. context necessarily implies examination of not only the ways in which it has been employed, but also the political and literary implications of those uses.

Literary historians seem to unanimously agree that U.S. literature as such, as an embodiment of a truly national cultural manifestation in the sense of being significantly different from its European (and particularly British) counterparts, came into existence simultaneously with a sense of spatial appropriation. The social, political, and economic upheaval which resulted in the thirteen colonies' declaration of independence from Great Britain and claim to the right to self-government in 1776 had a cultural correspondence in the literary development of the newly formed United States. To the extent that writers, notably Washington Irving and James Fenimore Cooper, conscientiously exploited local settings, events, personages, and issues in their writing, a national literary identity began to take shape (although one which naturally reflected the multiple origins of its inhabitants). This sense of themselves as a separate unit of space, rather than as an "annex" to a "parent" empire, was both fomented by and itself encouraged a set of new psychological coordinates which became the basis of mainstream social identity: the perception of this "New World" as a land of pristine opportunity, the rejection of history and the past as corrupt and the concomitant emphasis on the present and future, a shift in the concept of personal identity and worth based on actions rather than inheritance or social order, a privileging of the individual over the collective, and an almost obsessive insistence on personal freedom tempered by accountability. At this early stage of U.S. history, the conept of regionalism functioned as a means of establishing a separate national identity in multiple ways-politically, socially, psychologically, and culturally. Its main objective was unquestionably that of creating unity and order in two dimensions: the actual physical, territorial space of the new nation and its psychic counterpart of an "imagined community," to use Benedict Anderson's term for the "shared sense of a present and of simultaneous participation in historical change" (Kaplan 1991: 241). 
For all practical purposes, this conception of regionalism remained essentially unchanged until the Civil War (1861-1865), when the illusion of national unity was seriously challenged by the confrontation of those who favored supremacy of the federal government and those who favored greater control in the hands of each state. These differences were exacerbated by economic issues revolving around the acceptance of slavery as practiced in the plantation economy of the South and the objections of the industrialized North, a debate which tended to be further drawn along geographical lines because each new territory and state had to vote on whether slavery would be allowed or outlawed in its space. This correlation between ideologies and geographical location fostered a transformation in the conept of regionalism from that of a national space to one of lesser extension, generally understood as the large subdivisions of national territory (in classic fashion, labelled the East, the North, and South, and the West, and sometimes including the Midwest). Ironically, although intended to crytallize identities, these regions were essentially as unarticulated and shapeless as such vast areas almost inevitably are, and thus served to divide but not really to define each entity.

One repercussion of this geographical differentiation, however, was its highlighting of the multiplicity of interests, ideologies, lifestyles, values, and ethnicities which made up the United States. These differences became even more marked in the post-Civil War period because of a series of rapid, signifiant changes prompted by the rise of industrialization, as has been widely acknowledged. Millicent Bell emphasizes the crucial change from a fundamentally rural society to an urban one: "the centralizing forces of American life increasingly concentrated economic and political power in the great cities, in the foci of industry and commerce. America's development into an urban civilization meant the draining of human energy from the farms and villages, and especially from the oldest region-New England [...]" (470). The population shift from rural to urban gave rise to one of regionalism's most treasured illusions, one which has become a classic theme of U.S. literature in general: nostalgia for the loss of a more innocent, fulfilling life which is perceived as being epitomized in a rural lifestyle defined by humans in harmony with each other and with their environment. Amy Kaplan (1991: 242) has suggested the regionalist writers' creative obsession with the past (real or imagined) indicates a "willed amnesia about founding conflicts, while they reinvent multiple and contested pasts to claim as the shared origin of national identity". She also reinforces the significance of post-Civil War territorial expansion in both the sociopolitical and literary imaginations: the U.S. was "in the process of securing the continental borders that now define it, through a series of 'forgotten' Indian wars," a situation which lead writers to "explore past and present borders and frontiers to imagine a community through exclusion as much as inclusion" (242). The dramatic changes which took place after the Civil War reinforced as issues some very fundamental dichotomies: local-national, individualcollectivity, rural-urban, and agricultural-industrial, among others, all of which were basic concerns of authors of the period.

Another important aspect of U.S. society during the latter half of the nineteenth century was its penchant for social reform movements. Acording to critic Philip Brian Harper, "foremost in national debate during the period are abolitionism, feminism, agrarian protest, and industrial labor conditions" (216). Harper defines "reform" as "an improvement in social and political condisitons that is brought about without a radical change in existent social and political structures" (216). He highlights as crucial legislation of the time the Fugitive Slave 
Act of 1850, which mandated the return of escaped slaves even from the North, and the Compromise of 1850 , which permitted admission of Western territories into the Union as nonslave states. Both of these connect geography, economis, and ethics. He also analyzes the National Grange, the Greenback movement, and the Populist Rovolt as "mechanisms for protest" prompted by the "struggle of farmers of the West and South with the industrial and financial center of the East as the country's economic base shifted from agriculture to manufacture:

\footnotetext{
the mechanization of farming produced glutted markets and low crop prices, the development of railroad monopolies provided for high transportation costs [. . .]; a series of natural disasters made the welfare of rural families uncertain [. . . ]; immigration and the opening of public lands in the West to homesteading increased the size and diversity of the rural population to such an extent that it was difficult for them to meet on common social territory to address their concerns (234-5).
}

Feminist movements aligned themselves with civil rights and labor rights causes, in attempts to modify the social conditions which discriminated against minorities and marginalized them through differentiated status, retribution, and political rights-an alignment which, ironically, frequently had the effect of diluting rather than reinforcing the importance of the issues endemic to each group.

Industrialization also affected the world of publishing in significant ways. Acording to Ann D. Wood, until the late eighteenth century, authorship was more "a matter of finding a paying patron than of pleasing a reading public," but by the turn of the nineteenth century, "a wide and competitive literary market was becoming a reality" (6). In Golden Multitudes: The Story of Best Sellers in the United States, Frank Mott demonstrates that "printing was revolutionized in the 1840 s, allowing a drop in price for the average book from several dollars to a dollar or fifty cents" (Wood 1971: 33). Wood suggests that U.S. women authors were attracted to writing in part because of its business potential, which offered them the possibility not only of self-support and independence, but also of enjoying the professional status and privileges previously available only to men. She also asserts that the general process of increasing professionalization which took place in the nineteenth century tended to exclude women from other professions, at the same time that after the Civil War women fought for increased participation in all professional fields. According to Michael Bell, the issue of authorship was further complicated by changing social perceptions of the status of the writer from "a type of greatness" to "simply" a profession, and complicated even more by society's questioning the manhood of the male author as women began to dominate the market (27-9). Boston competed with New York for the status of center of the newly industrialized publishing world, and the combination of a more educated reading public and new technology-not to mention increasing prosperity-lead to a significant increase in the number of magazines being published. Among these, the Atlantic Monthly, Scribner's, and The Century-the socalled "genteel" magazines-dominated the literary tastes and values of the vast middle-class reading public.

Developments in the publishing institutions both manifested and influenced changing literary phenomena. Before the Civil War, U.S. fiction was dominated by a type of domestic writing often called "sentimentalism," a prose form directed toward the expanding audience 
of women readers who, as a result of technological advances and increased education and prosperity, had the novelty of indulging in leisure reading. Characterized by conventionality and melodrama, this fiction revolves around the "cult of domesticity" by appealing to "sentiment-by which they meant the heart, the emotions, the sympathy, of the individual" (Apthorp 5). Unquestionably the "bestsellers" of their time, the stories and novels by (now mostly forgotten) authors such as Ann Stephens, Elizabeth Oakes Smith, Maria Susanna Cummins, Lydia H. Sigourney, Susan Warner, and notably, Harriet Beecher Stowe, not only defined the domestic novel of the time, but also forced subsequent writers and publishers to take into account their female readership (Ammons 1991: 271). While there is considerable debate concerning the aesthetic value of many of these authors' private and public agendas, their social and literary influence is indisputable- too often only their surface of romantic domesticity is perceived, a surface which in reality served as a springboard for examining fundamental social issues, especially those related to gender and class. Like other versions of U.S. Romanticism, sentimentalism rather abrupty declined with the advent of the grim reality of civil war.

At the risk of greatly oversimplifying, for present purposes it can be said that the postCivil War literary climated was transformed by a new perspective-realism-which is frequently perceived as dominating U.S. literary prose well into the twentieth century (with Naturalism seen as a period of "extreme" or "distorted" realism, depending on the perceptions of the literary historian). As Michael Bell has emphasized. realism is most effectively dealt with not in terms of a coherent tradition, but rather in terms of how it is perceived by both those who embrace it and those who resist, and the repercussions of those perceptions (6). Amy Kaplan's differentiation between realism defined on formalist grounds and the use of realism to designate a literary historical period between the Civil War and World War I highlights the potential for debate surrounding this key aspect of U.S. literature, which concomitantly reinforces its importance as "a strategy for imagining and namaging the threats of social change [...] [as] an enormous act of construction to organize, re-form, and control the social world" (1988: 10). She perceives realists as "preoccupied with the problem of inhabiting and representing [...] space" (12), to which I would add that "space" in this context includes positioning in many dimensions: national and regional, collective and personal, literal and metaphorical. Having established a historical basis for this literary phenomenon, of greatest interest at this point is the insertion of "regionalism" and "local color" within this social and literary context of "realism."

Rather paradoxically, both "regionalism" and "local color" have ben used not only to designate a specific period of U.S. literary development but also to identify a type of literature. As a period, they are generally understood to refer to the decades of the $1880 \mathrm{~s}$ and $1890 \mathrm{~s}$, but it is not uncommon for the beginnings to be extended to "post-Civil War" (1865) or the 1870s, and the declining years to include the first decade or so into the twentieth century. As literary subgenres, they encapsulate a kind of writing which conscientiously and insistently exploits physical context for literary ends. Their conceptualization as a subgenre tends to tacitly exclude time limitations, since in this sense they can be exploited to describe authors as diverse as Washington Irving, William Faulkner, and Sandra Cisneros. To further complicate matters, some critics and literary historians use them interchangeably, while others carefully differentiate between them. Traditionally either use, especially when dealing with "local color," has tended to be perceived as at least somewhat pejorative, whether intended as such 
or not. By labelling a writer "regionalist" or "local colorist," the customary perception is that any larger application of "meaning" or import is either impossible or inappropriate. Underlying this perception, of course, is a concept of literature which claims ownership not only of aesthetic universals but also of human "truth," or more accurately, fails to recognize such claims as just that-appropriations-rather than as givens. From theoretical perspectives such as those of Tompkins, Kaplan, or Bell, the the derogatory usage of these terms itself illustrates how literature fulfills social and political, as well as aesthetic, functions - in other words, of the cultural work of fiction.

Not surprisingly, attempts to characterize regionalist and local color writing are a varied as the number of critics so engaged, and the traits ascribed to such literature tend to manifest the critic's perceptions of the functions it has. Even those authors identified with each tendency frequently vary. However, conventional lists of regionalist authors of the late nineteenth century tend to include a wide range of authors (see the annexed list), both male and female, each of which is associated with a specific geographical area. In contrast, "local color" writers are almost exclusively female and tend to be identified with more restricted locales. For example, Mark Twain and William Faulkner are often identified as regionalist writers, the former in the sense that he writes about the Mississippi River and its environs and the latter for his fiction about the South, while Kate Chopin has often been identified as a "local color" writer for her Louisiana stories and Sarah Orne Jewett for her writing about Maine. When not considered synonymous, local color is often labelled a subcategory of regionalism, or barely mentioned as a very minor literary phenomenon. Clearly both the labels and the seriousness with which this fiction is treated are intertwined with larger ideological issues within and beyond the literary institution.

It is also important not to lose sight of the fact that contemporary uses and perceptions of the terminology "regionalism" and "local color" do not necessarily correspond with those of the writers and critics involved in those movements during the last century, as Judith Fetterley and Marjoried Pryse remind us in their introduction to American Women Regionalists: "white men did not write the same kinds of regional texts that some white women or some members of minority groups did [...]. In using the term 'regionalism' to describe the body of literature collected here, we are aware that we may be more selfconscious about the connections between these texts than were the writers themselves" (xi). Fetterley and Bryse assert that regionalist writers did not necessarily differentiate between their own writing and that of their contemporaries, at the same time that they affirm that "in practice" regionalists did differentiate themselves from local colorists "primarily in their desire not to hold up regional characters to potential ridicule by eastern urban readers but rather to present regional experience from within, so as to engage the reader's sympathy and identification" (xii). All regionalist and local color literature emphasizes physical setting as a determinant element and concerns itself with the relationships between self and place (home, community, region). Among the major factors sometimes identified as significantly differentiating the two forms are those of narrative perspective and participation, authorial tone and intention, the relationships between character and setting, and the role of fiction as both manifestation of and response to changes in the context.

According to Diana Campbell, "rigid, politically defined regionalism had helped to cause the [civil] war, now a literary, nonpolitical version of regionalism would help to heal the 
nation's spiritual wounds" (19). Campbell asserts that local color fiction gained popularity after the Civil War "becasue of, not in spite of, its fixation on [...] absence, loss, limitation, and the past" (19), and she characterizes it as a strategic reaction to that fragmentation and loss:

\begin{abstract}
As increasing urbanization, industrial and technological growth, and rapid advances in transportation created a sense of uncontrolled and uncontrollable growth, readers welcomed a literature that defined specific parameters and identifiable codes of conduct [...]. The local colorists offered an appearance of order, closure, and humanity in a world that increasingly failed to provide them [...] . [L]ocal color [...] presents the same comforting illusion: the opportunity for control in a recent past that, unlike the present, permits not only problems on a human scale but the luxury of choice (23).
\end{abstract}

She suggests that local color writers depict a "doubly distanced golden age" by constituting the past in two parts: "a peaceful golden age of prosperity, projected as always absent from and prior to the second era, the hard times that characterize the recent past," thus fomenting "the reassuring myth that despite the upheavals of the Civil War and increasing industrialization, as well as the threat of immigration, a set of simple, enduring values and an age of moral certainty still existed with the isolated villages described in local color fiction" (20-1). According to Campbell, local color fiction "celebrates the preservation, through writing, of the lives of humble, ordinary people in an environment threatened by time, change, and external disruption" (7). She sees local color and naturalism as sharing "a commitment to the accurate and detailed representation of ordinary human beings," which characterizes realism, and "a belief in the shaping power of the environment" (9).

Like Campbell, Amy Kaplan sees a preservationist intent to regionalist writing (and like Campbell, she does not distinguish between the two terms). Kaplan suggests that the "profusion of literature known as regionalism or local color contributed to the process of centralization or nationalization [...] by reimagining a distended industrial nation as an extended clan sharing a 'common inheritance' in its imagined rural origins" (250-1):

\begin{abstract}
On the one hand, regionalist fiction expands the boundaries of the imagined community and democratizes access to literary representation, which can be heard in the multivocal introduction of the vernacular through the dialect of different regions. On the other hand, regionalism contained the threatening conflicts of social difference [...] . By rendering social difference in terms of region, anchored and bound by separate spaces, more explosive social conflicts of class, race, and gender made contiguous by urban life could be effaced. The native inhabitants of regional fiction could be rendered, on the one hand, as "the folk," the common heritage from which urban dwellers had simply moved, always available for return (251).
\end{abstract}

Kaplan also agrees with Campbell that although "region" often "first appears as the projection of a desire for a space outside of history [...] this projection is always challenged by a counter story and a prior history" (1991: 252). This concept of regionalist writing as "allegories of desire" is precisely what allows it to be perceived both as separatist and as centralizing, depending upon the ideological position of the critic.

In Breaking Boundaries: New Perspective on Women's Regional Writing, editors Sherry Inness and Diana Royer present a contrasting view of regional riction as a kind of writing which "highlights cultural and geographical differences" and "allows its practitioners a decentered perspective of the dominant culture's values [...] [which] lies at the heart of the 
power [it] has to critique society's values" (2). In emphasizing differences, they join critic David Jordan in assertng that "it has become clear that regionalism is more than just nostalgic 'local color,' but that it comprises a dynamic interplay of political, cultural, and psychological forces" (qtd. In Inness 2). Like Judith Fetterley and Marjorie Pryse, they examine how regionalist literary conventions, such as the use of simple stock characters, local dialect and customs, and geographical settings, go beyond mere descriptive representation to more fundamental issues of identity, narratology, gender, and ideology.

Fetterley and Pryse, however, insistently differentiate between regionalist and local color writing. According to them, the narrator of a regionalist text does not distance him/herself from the inhabitants of the region, as is the case in "local color" fiction: "The regionalist narrator empowers the voice of regional characters, viewing them as agents of their own lives, rather than undermining them with the ironic perspective characteristic of 'local color writing," [...] [which] fosters an empathic connection between the reader of the work and the lives the work depicts" (xvii). Kaplan points out that although "regional inhabitants could also be rendered as exotically other," their exoticness was "more familiar and less threatening" than the foreignness of the "feared flood of immigrants" (1991: 251). Fetterley and Pryse see local colorists as characterized by a narrative perspective "defined as superior to and outside of the region of the fiction" which exploits that region "often to entertain and satisfy the curiosity" of eastern urban readers (xii). Ann Petry, however, asserts that, in general, "the local colorists' respect for their characters is so deep that they do not indulge in [...] attempts to amuse their readerships or audience at the expense of their characters" (118). Petry's observation responds to her personal agenda of fostering re-evaluation of local color writing as an instance of not only national but even universal values, in an attempt to combat its traditionally low literary status. Kaplan, Fetterley, and Pryse, in contrast, are interested in how regionalist and local color writers both position themselves and are positioned by the larger national social community.

One major issue for literary critics and historians concerned with regionalist writing revolves around valuation of the form either as an opportune (or, to some, opportunistic) appropriation or as a limitation. Traditionalists tend to perceive the latter, while feminists tend toward the former. According to Donna Campbell, William D. Howells, the acknowledged mentor of U.S. regionalism in the publishing circles of the late nineteenth century, agreed with James Lane Allen's claim that "the writer must lay upon his canvas those colors that are true for the region he is describing and characteristic of it" by "employing formulaic local color elements such as dialect, stock characters, or dry humor not as mere 'colorful' decoration, but to explain regional variations in human behavior" (qtd. in Campbell 17-8). This conscientious representation of the details of daily lives, however, lead Frank Norris, among others, to make the following sarcastic remarks (which literally address realism, but are directed towards local color fiction): "Realism is minute, it is the drama of a broken teacup, the tragedy of a walk down the block, the excitement of an afternoon call, the adventure of an invitation to dinner [...]. Realism bows upon the doormat and goes away and says to me, as we link arms on the sidewalk: 'That is life" " (qtd. in Campbell 4). In a similar vein, Sinclair Lewis, in his well-known Nobel Prize speech in 1930, criticized such "tea-table gentility" and Howells' defense of it as follows: "Mr. Howells was one of the gentlest, sweetest, and most honest of men, but he had the code of a pious old maid whose greatest delight was to have tea at the vicarage" (qtd. in Campbell 5). 
It is in such observations as those given above that the intimate connections between gender and literary judments become most obvious. As suggested previously, women authors were unconditionally the best-selling authors of the mid- and late-nineteenth century in the U.S., to the point that Nathaniel Hawthorne, in a manly fit of pique, once described them as "that damned mob of scribblin' women." In the same manner that many see realism as a reaction towards Sentimentalism and Romanticism, the naturalism which followed regionalist and realistic literature has been perceived by some as a rejection of "local color's self-impsed limitations of style, form, and subject, and with them, the 'feminine' values at the heart of the movement" (Campbell 7). Campbell goes as far as to suggest that the opposition of realism and naturalism encompasses inherent questions of "the representation or construction of a carefully crafted and ideologically inflected 'reality'; and the oppositions of high culture and low and their metonymic counterparts of the literary East and the roughneck West" (6). Eric Sundquist is even more adamant in his reading of the dichotomy:

[E]conomic or political power can itself be seen to be definitive of a realist aesthetic, in that those in power (say, white urban males) have been more often judged 'realists,' while those removed from the seats of power (say, Midwesterners, blacks, immigrants, or women) have been categorized as regionalists (qtd. in Campbell 6).

Feminist critics have tended both to perceive and to evaluate regionalist and local color writing (especially that of women) differently. In "Sentimentalism, Naturalism, and the Female Regionalist," critic Elaine Apthorp praises the female local colorists for their acceptance that "human perception is inevitably subjective-the product of creative interaction between the senses and the soul, between data and desire" "nd for their belief that "human beings create their worlds, and that it is in our power to bridge these worlds in healing ways [...] through a kind of intersubjectivity, empathy, or sympathetic imagination" (11). In "Distilling Essences: Regionalism and 'Women's Culture', Marjorie Pryse suggests that women "discovered the strategies of regionalism as a 'hearth' or source of literary authority that gave them a literary "home" (12). In "The Literature of Impoverishment," Ann Wood affirms that women local colorists implicitly praised "the richness of womanhood and the plenitude of their resources" by concentrating on "domestic feminine virtues" (9), and that for them, "the act of writing offered [...] a release for despair" for their "lost faith in their potency" (16). In "Female Regional Writing," Millicent Bell sees female regionalism as "a return to a tradition oder than patriarchy $[. .$.$] the matriarchal stronghold where female strength preserved the bonds$ of community and the vital relation of humanity to nature" (473). Campbell agrees with Elizabeth Ammons in suggesting that "in articulating the form of their fiction, the local colorists imposed limitations that forced them to mimic their characters' own struggle. In articulating their themes, they promoted the idea of strength in, indeed through, limitation" (22). Many feminist critics have also highlighted the issue and art of women's "storytelling" both as selfpreservation and as essential strengthening and extension of communal values and ties.

Most literary historians see regionalism and local color (as literary movements) as peaking in the 1880 s. Kimball King has gone so far as to suggest that local color literature was relatively shortlived because it was little more than a "bland mixture of platitudes acceptable to purposes of an editorial campaign to 'shape' the thinking of the American middle class [...] [for which] [t]he magazine was the proper medium for reaching the masses, 
and local color was felt to be the literary movement best suited to an audience inexperienced but eager to learn" (qtd. in Campbell 185). In May, 1896, Charles Dudley Warner made a similar judgment: " 'Local color' has a fine run while it lasted [. . . [but] so much color was produced that the market broke down. It was an external affair, and its use was supposed to serve the gospel of Realism" (qtd. in Campbell 50). Changes in publishing and the reading public also contributed to the demise of regionalist and local color fiction: for example, the perfection of a photoengraving process that allowed cheaper magazine printing; a younger generation of writers and readers who were less tied to the Civil War; greater emphasis on the commercial potential of magazines and aggressive marketing techniques of new popular magazines such as McClure's, Collier's, and The Saturday Evening Post; and the reading public's new interest in historical romance and adventure stories. Political expansionism also drew attention away from the local to extended national and international arenas. Authors such as Frank Norris, Stephen Crane, and Theodore Dreiser aggressively promoted their own naturalistic world vision (and masculine authority) as more valid and objective than that of the local colorists and regionalists. Campbell also suggests that "[a]s early as the mid-1890s, [...] the term local color itself had undergone a metamorphosis, regaining its more general sense of 'qualities of a region' as it encompassed more urban settings" (61). As the nation turned to the new century, its authors and readers changed along with it, leaving "regionalism" and "local color" tendencies behind.

Far from being insignificant or minor aspects of U.S. cultural and literary development, regionalism and local color fiction grapple with very fundamental issues of the individual versus the group, gendered individualism, idealism versus pragmatism, and identity spheres. As Marjorie Pryse has so aptly surmised, "theorizing" regionalism is thus unavoidably "an attempt to specify what critical assumptions lie behind the process of drawing inferences from these texts that have led us to propose that the texts form a coherent tradition" (2). Regionalism's divergent faces paradoxically stretch from the conservative to the subversive, the mundane to the sublime, the ordinary to the extraordinary, in representing the multiple cultural visions. They run the gamut from fomenting an oxymoronic national identity of diversity to challenging this identity by opening spaces and inventing alternatives. Perhaps the only truly shared premise among those who participate in literary regionalism--whether as writers, readers, publishers, or critics—is that "place" is inherently political, whether explicitly acknowledged as such or not, in that it both constitutes and is constituent of human reality. 


\section{Appendix A: \\ Regionalist Writers in Nineteenth-Century U.S. Literature (taken from Donna Campbell's Resisting Regionalism, 14-19)}

New England (Vermont): Rowland E. Robinson (1833-1900)

Massachussetts: Mary Wilkins Freeman (1852-1930)

Maine: Sarah Orne Jewett (1849-1930), Harriet Beecher Stowe (1811-1896)

New Hampshire: Alice Brown (1857-1948) and Celia Thaxter (1835-1894)

Midwest: Edward Eggleston (1837-1902), E.W. Howe (1853-1894), Hamlin Garland (18601940)

Michigan: Constance Fenimore Woolson (1840-1894)

Arkansas and Iowa: Alice French (1850-1934) (pseudonym Octave Thanet)

West: Mary Austin (1868-1934) and Zitkala Sa (Gertrude Simmons Bonnin) (1876-1938), Bret Harte (1836-1902)

Tennessee: Mary Noailles Murfree (as Charles Egbert Craddock) (1850-1922)

Kentucky: James Lane Allen (1849-1925)

Georgia: Joel Chandler Harris (1848-1908)

Virginia: Thomas Nelson Page (1851-1932)

Louisiana: Kate Chopin (1850-1904), Grace King (1851-1932), George Washington Cable (1844-1925)

South: Alice Dunbar-Nelson (1875-1935), Charles Waddell Chusnutt (1858-1932)

Mississippi: Mark Twain (1835-1910)

Connecticut: Rose Terry Cooke (1827-1892)

\section{Works Cited}

Ammons, Elizabeth. 1991. "Gender and Fiction." The Columbia History of the American Novel. Ed. Emory Elliott. New York: Columbia UP: 267-84.

Apthorp, Elaine Sargent. 1990. "Sentiment, Naturalism, and the Female Regionalist." Legacy 7: 3-21.

Bachelard, Gaston. 1994. The Poetics of Space. Trans. Maria Jolas. Boston: Beacon.

Bell, Michael Davitt. 1993. The Problem of American Realism: Studies in the Cultural History of a Literary Idea. Chicago: U Chicago P.

Bell, Millicent. 1986 "Female Regional Writing: An American Tradition." Revue Française de'études Américaines: 469-80.

Campbell, Donna M. 1997. Resisting Regionalism: Gender and Naturalism in American Fiction, 1885-1915. Athens: Ohio UP. 
Fetterley, Judith and Marjorie Pryse (Eds). 1992.American Women Regionalists. New York: Norton.

Harper, Philip Brian. 1991. "Fiction and Reform II." The Columbia History of the American Novel. Ed. Emory Elliott. New York: Columbia UP. 216-39.

Inness, Sherry and Diana Royer (eds.) 1997. Breaking Boundaries: New Perspecitves on Women's Regional Writing. Iowa City: U Iowa P.

Kaplan, Amy. 1991. "Nation, Region, Empire." The Columbia History of the American Novel. New York: Columbia UP: 240-66.

1988. The Social Construction of American Realism. Chicago: U Chicago P.

McLauglin, Thomas. 1995. "Introduction." Critical Terms for Literary Study. $2^{\text {nd }}$ ed. Eds. Frank Lentricchia and Thomas McLaughlin. Chicago: U Chicago P.

Petry, Alice Hall. 1979. "Universal and Particular: The Local-Color Phenomenon Reconsidered." American Literary Realism 1870-1910. XII: 111-26.

Pryse, Marjorie. 1993. “Distilling Essences: Regionalism and 'Women's Culture.'” American Literary Realism 1870-1910. XXV: 1-15.

Tompkins, Jane. 1985. Sensational Designs: The Cultural Work of American Fiction 17901860. New York: Oxford.

Wilson, Christopher P. 1991. "Introduction: The Late Nineteenth Century." The Columbia History of the American Novel. New York: Columbia UP: 157-59.

Wood, Ann D. 1971. "The Literature of Impoverishment: The Women Local Colorists in America 1865-1914". Women's Studies 1: 3-45. 